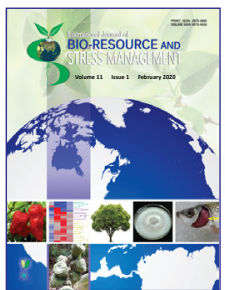

\title{
Yield Performance and Economic Analysis of Pigeon pea (Cajnus cajan) Through Front Line Demonstration under Rainfed Condition of Tarai Region of Uttar Pradesh
}

\author{
Narendra Singh
}

Dept. of Agronomy, Banda University of Agriculture and Technology, Banda, Uttar Pradesh (210 001), India

6

Open Access

\section{Corresponding Author}

Narendra Singh

e-mail: narendra.buat@gmail.com

Citation: Singh, 2020. Yield Performance and Economic Analysis of Pigeon pea (Cajnus cajan) Through Front Line Demonstration under Rainfed Condition of Tarai Region of Uttar Pradesh. International Journal of Bioresource and Stress Management 2020, 11(3):264-267. HTTPS://DOI.ORG/10.23910/1.2020.2039a.

Copyright: (c) 2020 Singh. This is an open access article that permits unrestricted use, distribution and reproduction in any medium after the author(s) and source are credited.

Data Availability Statement: Legal restrictions are imposed on the public sharing of raw data. However, authors have full right to transfer or share the data in raw form upon request subject to either meeting the conditions of the original consents and the original research study. Further, access of data needs to meet whether the user complies with the ethical and legal obligations as data controllers to allow for secondary use of the data outside of the original study.

Conflict of interests: The authors have declared that no conflict of interest exists.

\begin{abstract}
Seventy five demonstrations in the farmers' fields were conducted on Pigeon pea during 2009-10 to 2013-14 in 5 adopted locations (villages) namely Khajurinidhi, Sukulan purwa, Jai Prabha gram, Chhiras and Peoli of Gonda district, Uttar Pradesh state, India under Tarai agro-climatic zone. The critical inputs were prioritized according to gap analysis on existing production technologies through Participatory Rural Appraisal (PRA), farmer's interaction and feedback. In demonstration plot, latest recommended package of practices were adopted as good quality seed, weed management, integrated nutrient management, timely sowing on ridges were made to reduce crop mortality due to water logging and management of pests at proper time. The 5 -years data revealed that an average higher yield of demonstration field was obtained $1.831 \mathrm{t} \mathrm{ha}^{-1}$ over local check (1.002 $\left.\mathrm{t} \mathrm{ha}^{-1}\right)$ with additional yield of $0.829 \mathrm{t} \mathrm{ha}^{-1}$ due to timely technological support in demonstration fields. Similarly, net average economic return of

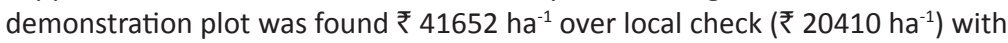
additional return of ₹ $21242 \mathrm{ha}^{-1}$. The average technological gap, extension gap, technological index and increased B:C ratio were found $0.969 \mathrm{t} \mathrm{ha}^{-1}, 0.829 \mathrm{t}$ $\mathrm{ha}^{-1}, 34.61 \%$ and 0.95 , respectively. Data revealed significantly impact of latest technologies in compare to traditional Pigeon pea cultivation under demonstrated farmer's fields during the years.
\end{abstract}

Keywords: Pigeon pea, front Line Demonstrations, yield gap, economics

\section{Introduction}

Pigeon pea (Cajanus cajan) is an important kharif season (July to March) pulse crop regarding area and production in the country. In India cultivation of legumes forms an integral part of the rainfed production system, however, their productivity over the years has remained low and unstable (Bhatia et al., 2005). Thus total pulse production in India is not able to meet out its total demand. To work out a suitable strategy to improve the productivity of Pigeon pea, it is imperative to assess the potential yield in the region of interest and gap between the potential yield and actual yield obtained by the average farmers (Bhatia et al., 2005). Presently, the pulses are grown approximately 23 mha with 13-15 $\mathrm{mt}$ of production. In the past 5 decades, pulse production has not kept up with growth in demanding calling for import to the tune of 0.5 to 1.5 $\mathrm{mt}$ (Roy et al., 2006). In India a considerable amount of agricultural land remains fallow during rainy season which could be potentially explored for expansion of pulses area. But low productivity, low potential varieties,

\section{Article History}

RECEIVED in $24^{\text {th }}$ September 2019 RECEIVED in revised form $17^{\text {th }}$ June 2020 ACCEPTED in final form $19^{\text {th }}$ June 2020 
high crop - weed competition, crop loses due to insect-pest are major factors which prohibit the expansion of Pigeon pea area. A good quality seed and weed management enhance the productivity of Pigeon pea (Vijay kumar et al., 1995). The response of Front Line Demonstrations on maximization of pulses yield was also found better in compare to traditional farming (Raju et al., 2015 and Jaylakshmi et al., 2018). In Uttar Pradesh, during 2016-17 the total area under cultivation was $0.34 \mathrm{mha}$ with total production of $0.36 \mathrm{mt}$. The average productivity of Pigeon pea was $1.074 \mathrm{t} \mathrm{ha}^{-1}$ which was recorded lower than the leading state like Madhya Pradesh (1.133) t ha-1 (Anonymous, 2018). Though Pigeon pea is a major kharif pulse crop grown almost all part of the state under different agroclimatic condition but a huge yield gap exist between potential yield and yield under real farming situation. District Gonda is a part of north-eastern plain zone of the state falls under Tarai agro-climatic condition. The average productivity of district Gonda was $0.761 \mathrm{t} \mathrm{ha}^{-1}$ in 2007-08 which was very poor in comparison to present state yield (1.167 t ha ${ }^{-1}$ ) (Anonymous, 2008). It might be due to improper management of the crop under water logging condition, crop-weed competition and plant protection. Apart from all other approaches to increase the average productivity of this crop, front line demonstrations have been conducted to disseminate and evaluate recommended technologies among the Pigeon pea producing farming community.

\section{Materials and Methods}

The study was carried by LBS KVK, Gonda district, Uttar Pradesh state, India during kharif season (July to March) during 2009-10 to 2013-14 (5 consecutive years) in the farmers' field of 5 adopted locations (villages) namely Khajurinidhi, Sukulan purwa, Jai Prabha gram, Chhiras and Peoli of Gonda district (UP). During these 5 years of study, an area of 30 ha was covered with plot size 0.4 ha under each demonstration on progressive farmers' field. Total 75 field demonstrations (15 each year) were conducted to assess the performance of latest technologies over tradition farming practices. The selection of farmers has done after group meeting and PRA analysis at village level. It was kept in mind that selection of different locations (villages) truly represents the Tarai agro-climatic condition. Before conducting Front Line Demonstration (FLD) specific skill training were imparted to identify farmers regarding different cultivation management practices of Pigeon pea.

In general, soils under study were sandy loam to clay loam in texture with a $\mathrm{pH}$ range 7.0 to 7.5. The available Nitrogen, Phosphorus and Potassium were recorded between 110-160, 18-23 and 380-430 $\mathrm{kg} \mathrm{ha}^{-1}$, respectively. In demonstration plot, latest recommended package of practices were adopted as good quality latest variety seed, weed management, integrated nutrient management, timely sowing on ridges to reduce crop mortality due to water logging and management of pests at proper time. The comparison of Front-Line
Demonstration technologies in which we provide latest inputs to maximize the productivity and existing farmers practice (Local check) were given in Table 1. All necessary steps for conducting scientific Front-Line Demonstration were taken according to suggestion made by Chaudhary (1999). Both

Table 1: Comparison between demonstration and local check production practices of Pigeon pea

\begin{tabular}{|c|c|c|c|}
\hline $\begin{array}{l}\text { Sl. } \\
\text { No. }\end{array}$ & Particular & Demonstration & Local check \\
\hline 1. & $\begin{array}{l}\text { Farming situ- } \\
\text { ation }\end{array}$ & Irrigated & Irrigated \\
\hline 2. & Variety & $\begin{array}{l}\text { Narendra Arhar } \\
-1\end{array}$ & Bahar \\
\hline 3. & Sowing time & 10-15 July & 10-15 July \\
\hline 4. & $\begin{array}{l}\text { Method of } \\
\text { sowing }\end{array}$ & $\begin{array}{l}\text { Line sowing on } \\
\text { bunds at } 45 \times 45 \\
\mathrm{~cm}^{2} \text { Spacing }\end{array}$ & Broadcasting \\
\hline
\end{tabular}

5. Seed treatment Carbendazim @ 1 No seed treat$\mathrm{g} \mathrm{kg}^{-1}$ seed ment

6. Seed inocula- Rhyzobium cul- No seed inocution ture @ $400 \mathrm{~g}$ and lation PSB @ $400 \mathrm{~g} / 10$ kg seed

7. Seed rate $12.5 \mathrm{~kg} \mathrm{ha}^{-1}$ $15 \mathrm{~kg} \mathrm{ha}^{-1}$

8. Fertilizer dose NPK(20:60 20) NPK (16:48)

9. Weed manage- Pendimathelene Onehandweedment @ $1.25 \mathrm{~kg}$ a.i. ha ${ }^{-1}$ ing at 45 DAS As pre emergence followed by 1 hand weed-ing at 35 DAS

10. Irrigation One irrigation at No irrigation pod filling stage

11. Plant protec- Two application One spray of tion of Monocroto- any available phos@1.2। ha-1 insecti-cide acat flowering and cording to shoppod filling stage keeper ad-vise to control pod fly after Attack of and pod borer borer

plots were managed according to plan and required data were recorded from both FLD and Local check plots and finally the extension gap, technology gap (Samui et al., 2000), net return and benefit cost ratio were worked out as given below -

Technology gap=Potential yield-Demonstration yield

Extension gap = Demonstration yield-Local check yield

Technology index $(\%)=($ Technology gap $\div$ Potential yield) $\times 100$ 
$\%$ increased over local check= (Demonstration yield-local check) $\div$ Demonstration yield $\times 100$

Net return ( $\left(\right.$ ha $\left.a^{-1}\right)=$ Gross cost $\left(₹\right.$ ha $\left.{ }^{-1}\right)-$ Gross return ( $\left(h^{-1}\right)$

$\mathrm{B}: \mathrm{C}$ ratio $=$ Gross return $\left(₹ \mathrm{ha}^{-1}\right)$

\section{Results and Discussion}

\subsection{Yield performance}

The data of Table 2 revealed that the productivity of Pigeon pea fluctuated remarkably over the year in demonstration plot. The highest yield was recorded $\left(2.075 \mathrm{t} \mathrm{ha}^{-1}\right)$ during 2013-
14 and lowest yield was recorded in the year 2011-12 (1.68 t $\left.\mathrm{ha}^{-1}\right)$ and the average yield of five year was found $1.831 \mathrm{tha}^{-1}$ over increase of $0.829 \mathrm{t} \mathrm{ha}^{-1}$ in compare to local check (1.002 $\mathrm{t} \mathrm{ha}{ }^{-1}$ ). The yield increased in per cent was ranging 38.99 to 47.95 during five years of study period. On an average 45.12 per cent increased yield was noted over local check. The results are in conformity with the findings of Jain et al. (1988), Tomar et al. (2003), Tiwari et al. (2011), Singh et al. (2014).

The results clearly indicate the positive effect of FLD over the existing production practices toward enhancing the yield of Pigeon pea in Tarai area of UP with the higher indicators

\begin{tabular}{|c|c|c|c|c|c|c|c|c|c|}
\hline \multirow[t]{2}{*}{ Year } & \multirow{2}{*}{$\begin{array}{r}\text { Area } \\
\text { (ha) }\end{array}$} & \multirow{2}{*}{$\begin{array}{l}\text { No. of } \\
\text { farmers }\end{array}$} & \multicolumn{3}{|c|}{ Seed yield ( $q \mathrm{ha}^{-1}$ ) } & \multirow{2}{*}{$\begin{array}{c}\% \text { increased } \\
\text { over check }\end{array}$} & \multirow{2}{*}{$\begin{array}{c}\text { Technology } \\
\text { gap }\end{array}$} & \multirow{2}{*}{$\begin{array}{c}\text { Extension } \\
\text { gap }\end{array}$} & \multirow{2}{*}{$\begin{array}{c}\text { Technology } \\
\text { index (\%) }\end{array}$} \\
\hline & & & Potential & Demo. & L. check & & & & \\
\hline $2009-10$ & 6.0 & 15 & 28.0 & 18.50 & 9.75 & 47.30 & 9.50 & 8.75 & 33.93 \\
\hline $2010-11$ & 6.0 & 15 & 28.0 & 17.20 & 9.15 & 46.80 & 10.80 & 8.05 & 38.57 \\
\hline 2011-12 & 6.0 & 15 & 28.0 & 16.80 & 10.25 & 38.99 & 11.20 & 6.55 & 40.00 \\
\hline $2012-13$ & 6.0 & 15 & 28.0 & 18.30 & 10.15 & 44.54 & 9.70 & 8.15 & 34.64 \\
\hline $2013-14$ & 6.0 & 15 & 28.0 & 20.75 & 10.80 & 47.95 & 7.25 & 9.95 & 25.89 \\
\hline Total & 30.0 & 75 & 140.0 & 91.55 & 50.10 & 225.58 & 48.45 & 41.45 & 173.03 \\
\hline Average & 6.0 & 15 & 28.0 & 18.31 & 10.02 & 45.12 & 9.69 & 8.29 & 34.61 \\
\hline
\end{tabular}

of yield attributes of Pigeon pea (Table 3). The increased of yield in FLDs mainly due to use of good quality seed of high yielding wilt resistant variety (NA-2), line sowing technology on bunds, proper and balance application of fertilizers which encourage timely and optimum growth of crop. Timely weed management also reduce the crop - weed competition in FLD plots which ultimately increase the plant canopy to produce more flowers and pods plant ${ }^{-1}$ (Vijay kumar et al., 1995, Hiremath and Nagaraju, 2010, Bairwa et al., 2013 and Vijaylakshmi et al., 2017).

Table 3: Yield parameters under demonstration package and existing farmers practice

\begin{tabular}{|c|c|c|c|}
\hline $\begin{array}{l}\text { Sl. } \\
\text { No. }\end{array}$ & Yield parameters & FLD package & $\begin{array}{l}\text { Farmers } \\
\text { practice }\end{array}$ \\
\hline 1. & No. of plants $\mathrm{m}^{-2}$ at 35 DAS & 13.5 & 10.2 \\
\hline 2. & No. of pods plant ${ }^{-1}$ & 350 & 225 \\
\hline 3. & No. of seeds pod ${ }^{-1}$ & 3 & 3 \\
\hline 4. & 1000 -seed weight ${ }^{-1}$ & 112 & 91.2 \\
\hline
\end{tabular}

The extension gap reflected a remarkable difference between demonstration yield and farmers yield. The extension gap ranging between 0.655 to $0.995 \mathrm{t} \mathrm{ha}^{-1}$ during the study period of 2009-10 to 2013-14 which need to give more attention on farmer's practices of production though various means of adoption of improved agricultural production technologies to reverse the trend of wide extension gap. The trend of technology gap (ranging between 0.725 to 1.120 t ha $^{-1}$ ) showed the farmers cooperation in carrying out demonstration with encouraging results in subsequent years. The difference recorded under technology gap may be attributing to the dissimilarities in soil fertility status and weather condition, especially in winter rainfall. Similar findings were recorded by Yadav et al. (1997).

The technology index showed the feasibility of adopted FLD technologies at the farmer's field. The lowest value of technology index $(25.89 \%)$ is the most feasibility of technology. The variation in technology index (ranging between 25.89 to $40 \%$ ) during the study period in Tarai region of UP may be attributed to the different level of soil fertility status, weather condition and insect - pest attack.

\subsection{Economic parameters}

The data of Table 4 reveals that gross return ( $₹$ ha ${ }^{-1}$ ) ranging between 46250 to 66400 during 5 years of study period with average gross return of $₹ 55680 \mathrm{ha}^{-1}$ in compare to local check of Rs. $30536 \mathrm{ha}^{-1}$. Similar trends was noted with net return (₹ $\mathrm{ha}^{-1}$ ) in which an average of ₹ $41652 \mathrm{ha}^{-1}$ was obtained more in FLD than average of local check of ₹ 20410 ha $^{-1}$ during 5 year. Similar findings were also reported by Dhaka et al., 2010. Both gross return and net return were recorded in increasing order from 2009-10 to 2013-14. Benefit: cost ratio was also recorded higher under demonstration against farmer practice during all 5 year study period with average increase of 0.95 over local check. Similar results were reported by Joshi et al. (2002), Mokidue et al. (2011), Sreelakshmi et al. (2012). 


\begin{tabular}{|c|c|c|c|c|c|c|c|c|c|}
\hline \multirow[t]{2}{*}{ Year } & \multicolumn{2}{|c|}{ Gross cost (₹ ha-1) } & \multicolumn{2}{|c|}{ Gross return (₹ ha-1) } & \multicolumn{2}{|c|}{ Net return $\left(₹ \mathrm{ha} \mathrm{a}^{-1}\right)$} & \multicolumn{2}{|c|}{$\mathrm{B}: \mathrm{C}$ ratio } & \multirow{2}{*}{$\begin{array}{l}\text { Increasec } \\
B: C \text { ratio }\end{array}$} \\
\hline & Demo & L. Check & Demo. & L. Check & Demo & L. Check & Demo & L. Check & \\
\hline 2009-10 & 12800 & 9200 & 46250 & 24375 & 33450 & 15175 & 3.61 & 2.65 & 0.96 \\
\hline 2010-11 & 13240 & 9775 & 51600 & 27450 & 38360 & 17675 & 3.90 & 2.81 & 1.09 \\
\hline 2011-12 & 13510 & 9923 & 53760 & 32800 & 40250 & 22877 & 3.98 & 3.31 & 0.67 \\
\hline $2012-13$ & 14290 & 10450 & 60390 & 33495 & 46100 & 23045 & 4.23 & 3.21 & 1.02 \\
\hline 2013-14 & 16300 & 11280 & 66400 & 34560 & 50100 & 23280 & 4.07 & 3.06 & 1.01 \\
\hline Total & 70140 & 50628 & 278400 & 152680 & 208260 & 102052 & 19.79 & 15.04 & 4.75 \\
\hline Average & 14028 & 10125 & 55680 & 30536 & 41652 & 20410 & 3.96 & 3.01 & 0.95 \\
\hline
\end{tabular}

1 US\$=₹ 45.46, 2010, 44.94, 50.27, 54.41, 61.04 (average of March of 2010, 2011, 2012, 2013, 2014 respectively)

\section{Conclusion}

Use of recommended production practice of Pigeon pea can reduce the technology gap ( 0.725 to $\left.1.120 \mathrm{t} \mathrm{ha}^{-1}\right)$ and increase the productivity of Pigeon pea $\left(1.831 \mathrm{t} \mathrm{ha}^{-1}\right)$ and economic returns to a considerable extent ( $\left.₹ 55680 \mathrm{ha}^{-1}\right)$ in the district.

\section{References}

Anonymous, 2019. Agricultural Statistics at a Glance 2018. Directorate of Economics and Statistics. Department of Agriculture, Cooperation \& Farmers Welfare. Ministry of Agriculture \& Farmers Welfare. Govt. of India, pp 100. Available at www.agricoop.nic.in \& http:// eands. dacnet.nic.in

Bairwa, R.K., Verma, S.R., Chayal, K., Meena, N.L., 2013. Popularization of improved Blackgram production technology through frontline demonstration in humid southern plain of Rajasthan. Indian Journal of Extension Education and rural development 21, 97-101.

Bhatia, V.S., Singh, Piara, Wani, S.P., Kesav Rao, A.V.S., Srinivas, K., 2006. Yield gap analysis of Soybean, Ground nut, Pigeon pea and Chick pea in India using simulation modeling Global theme on Agro ecosystem report no. 31. Indian International Crops Research Institute for Semi-arid Tropics (ICRISAT). A.P. India, 156.

Dhaka, B.L., Meena, B.S., Suwalka, R.L., 2010. Popularization of improved maize technology through frontline demonstration in south eastern, Rajasthan. Journal of Agricultural Sciences (1), 39-42.

Hiremath, S.M., Nagaraju, M.V., 2010. Evaluation of front line demonstration on yield of chilli. Karnataka Journal of Agricultural Sciences 23(2), 341-342.

Jain, N.K., Jain, H.C., Khandekar, U.R., 1988. Response of kharif legumes to fertilizers and Rhyzobium inoculation. Indian Journal of Agronomy (33), 347-350.

Joshi, P.K., Saxena, R., Saxena, R., 2002. A profile of pulse production in India: Facts, trends and opportunities. Sixty second annual conference of the Indian society of Agricultural economics held at ICAR, New Delhi 19-21, in
December, 2002. Indian Journal of Agriculture Economics 57(3), 326-339.

Mokidue, I., Mohanty, A.K., Sanjay, K., 2011. Correlate growth yield and adoption of Urdbean technology. Indian Journal of Extension Education 11(2), 20-24.

Raju, G.T., Patil, D.H., Naik, A., Zaheer ahamad, B., Patil, M.C., 2015. Impact of Front Line Demonstration on Yield and Economics of Pigeon pea in Kalburgi district of Karnatka. International Journal of Science and Nature 6, 224-227.

Roy, B.R., Singh, S.K., Singh, L., Singh, A.K. 2006. Adoption of improved pulse production technologies and related constraints in Uttar Pradesh. Indian Journal of Pulse Research 19(1), 104-106.

Singh, D., Patel, A.K., Baghel, S.K., Singh, M.S., Singh, A., Singh, A.K., 2014. Impact of Front Line Demonstration on yield and economics of Chick pea in Sidhi district of M.P. Journal of agricultural research 1(1), 22-25.

Sreelakshmi, C., Sameer Kumar, C.V., Shivani, D., 2012. Productivity enhancement of Pigeon pea (Cajanus cajan L.) Through Improved Production Technologies. Madras Agricultural Journal 99 (4-6), 248-250.

Tiwari, D.S., Sharma, B.B., Singh, V.K., 2011. Effect of Integrated Nutrient Management in Pigeon pea based cropping system. Journal of food legume 24(40), 304-309.

Tomar, L.S., Sharma, B.P., Joshi, K., 2003. Impact of front line demonstration of pulses in transfer of improved technology. Journal of Extension Education 22(1), 139.

Vijay Kumar, B., Reddy, M.N., Shivshankar, M., 1995. Integrated Weed Management in Pigeon pea- Ground nut inter cropping. Indian Journal of Weed Science 27, 12-15.

Vijaylakshmi, D., Vijay Kumar, P., Padma Veni, C., 2017. Impact of cluster front line demonstration to transfer of technology in pulses production under NFSM. Bulletin of Environment, Pharmacology and Life Sciences 6(1), 418-421.

Yadav, R.P., Sharma, R.K., Srivastav, U.K., 1997. Fertility management in Pigeon pea based cropping system under rainfed condition. Indian Journal of Agronomy 42, 46-49. 